\title{
Exploring perceptions of fracking and environmental health in a 3-county population in South Texas
}

\author{
Kristina W. Whitworth*1,2, Elisabeth De LaRosa ${ }^{1,3}$, Taylor Mackay ${ }^{1}$, Ashley Hernandez ${ }^{1}$, Mary K. Martin ${ }^{1}$, Jaime \\ Lopez $^{4}$, Monty Small ${ }^{5}$, Paula Winkler ${ }^{6}$, Melissa A. Valerio ${ }^{1}$ \\ ${ }^{1}$ UTHealth School of Public Health in San Antonio, San Antonio, Texas, USA \\ ${ }^{2}$ Southwest Center for Occupational and Environmental Health, UTHealth School of Public Health, Houston, Texas, USA \\ ${ }^{3}$ Institute for Integration of Medicine and Science, The University of Texas Health Science Center at San Antonio, San Antonio, \\ Texas, USA \\ ${ }^{4}$ Texas A\&M AgriLife Extension, Pearsall, Texas, USA \\ ${ }^{5}$ Atascosa Health Center Inc., Pleasanton, Texas, USA \\ ${ }^{6}$ ReACH Center, The University of Texas Health Science Center at San Antonio, San Antonio, Texas, USA
}

\author{
Received: September 23, 2016 \\ Accepted: January 9, 2017 \\ Online Published: February 14, 2017 \\ DOI: $10.5430 /$ jer.v3n1p61 \\ URL: https://doi.org/10.5430/jer.v3n1p61
}

\begin{abstract}
Introduction: The past decade in the United States has been marked by an unprecedented expansion of unconventional oil and gas drilling, including hydraulic fracturing (i.e., fracking). Concerns have arisen regarding potential health and environmental risks associated with the use of the fracking process. The purpose of this exploratory study was to examine community perceptions, concerns, and knowledge of environmental health issues related to fracking in three Texas counties near one of the most active shale plays in South Texas, the Eagle Ford Shale.

Methods: A convenience sample of 153 adults over the age of 18 years in three rural South Texas counties completed a 46question survey. Demographic information, perceptions of environmental health risks, and knowledge of potential environmental health effects related to fracking were obtained. A validated health literacy measure was also used to assess participants' health literacy.

Results: Participants were predominantly female (61\%), white (75\%), and Hispanic (62\%). A majority owned land (53.6\%) and had lived in their respective county for over 21 years (54\%). Only 32\% percent of participants had marginal or inadequate health literacy though a larger percentage of participants had limited knowledge of potential environmental health risks related to fracking.

Conclusions: Approximately one third of participants had less than adequate health literacy as measured by the BRIEF. A high percentage of the population demonstrated limited knowledge regarding the potential environmental health impacts of fracking, suggesting limited environmental health literacy. Findings point to the need for environmental health specific assessments and focused environmental health promotion strategies.
\end{abstract}

Key Words: Fracking, Hydraulic fracturing, Environmental health literacy, Health literacy, Community, Perceptions

\section{INTRODUCTION}

In recent years, the United States has experienced an unprecedented expansion of unconventional oil and gas drilling (UOGD), including hydraulic fracturing (i.e., fracking).
Fracking provides an economical method for capturing hard to reach oil and gas reserves trapped in tight shale formations. Between 2005 and 2013, the total production of dry natural gas increased by $35 \%$ in the United States and this growth is

\footnotetext{
* Correspondence: Kristina W. Whitworth; Email: kristina.w.whitworth@uth.tmc.edu; Address: UTHealth School of Public Health in San Antonio, San Antonio, Texas; Southwest Center for Occupational and Environmental Health, UTHealth School of Public Health, Houston, Texas, USA.
} 
forecasted to continue through 2040, largely due to the development of shale gas. ${ }^{[1]}$ Given this widespread expansion of oil and gas drilling in the United States, concerns have been raised regarding potential health and environmental risks associated with fracking process. ${ }^{[2]}$

UOGD involves multiple complex phases resulting in a range of potential chemical (e.g., air and water emissions), physical (e.g., noise), and safety (e.g., traffic accidents) hazards. ${ }^{[2]}$ Air or groundwater contamination may result during well pad construction, drilling and completion of wells, gas flaring, operations of heavy equipment and generators, spills or leaks from condensate tanks or material transfer operations, migration of fracking fluids through openings in well casings or natural fractures in the shale formation ${ }^{[2,3]}$ Further, in creases in heavy trucking traffic associated with the transport of materials during the UOGD process results in increased ambient levels of traffic-related air pollutants. ${ }^{[2,4]}$ Multiple studies have also documented increased concentrations of other air pollutants surrounding UOGD, including volatile organic compounds (e.g., benzene), particulates (including diesel PM), and polycyclic aromatic hydrocarbons. ${ }^{[2,5-9]}$

Shonkoff et al. ${ }^{[4]}$ point to the potential risks associated with water contamination, particularly related to wastewater transport and disposal. A recent study indicated high levels of endocrine disrupting chemicals measured in surface water samples downstream from wastewater disposal facilities associated with the oil and gas industry. ${ }^{[10]}$ A study conducted in the Barnett Shale area of North Texas reported measurable levels of compounds used in fracking fluid in groundwater samples though the source of the contamination was not known. ${ }^{[11]}$ However, a report from the U.S. Environmental Protection Agency (EPA) concluded that there was no evidence that the process of fracking has resulted in adverse impacts on drinking water. ${ }^{[12]}$

Overall, evidence of the potential health effects experienced among communities near UOGD activity is limited. ${ }^{[13]}$ While a risk assessment conducted in rural Colorado reported increased hazard indices for neurological, respiratory, hematologic, and developmental effects among residents within 1/2 mile of a UOGD well, compared to residents living further away, this study was based on limited monitoring in a relatively affluent community. ${ }^{[5]}$ Published epidemiologic studies of health effects associated with living near UOGD are scarce and the results are equivocal. ${ }^{[14-19]}$ Even less is understood regarding the perception of exposure by residents in communities surrounding high fracking activity. As a part of a health impact assessment conducted in a western Colorado community, residents reported concerns about how UOGD may negatively impact their community's sense of livability and cohesion as well as specific concerns regarding increases in crime and substance abuse and detrimental effects on land values. ${ }^{[20]}$

Although fracking has the potential to greatly impact the lives of residents in affected communities, little research has been conducted to examine residents' knowledge, attitudes and perceptions of fracking among communities near increased UOGD activity. We conducted an exploratory study to begin to identify perceived environmental health issues among residents of three rural South Texas communities. The present study was conducted in the Eagle Ford Shale (EFS), which stretches across 26 counties from the southwest Texas-Mexico border to East Texas. Covering an area approximately 50 miles wide and 400 miles long, the EFS is home to one of the world's largest oil and gas developments and represents a largely rural region of the state. ${ }^{[21]}$

\section{Methods}

The Partners for a Healthy Community and Environment (PaCE) project was a community engagement pilot project conducted in partnership with the Frio County Translational Advisory Board and the Karnes County Community Advisory Board which are part of the University of Texas Health Science Center at San Antonio, Institute for Integration of Medicine and Science (IIMS), Clinical Translational Science Award. The goal of PaCE, as defined by our partners, was to examine perceptions of the impact of UOGD in Atascosa, Frio, and Karnes counties. A cross-sectional survey was administered to a convenience sample of adults over 18 years of age in these three rural EFS counties. The survey was conducted in English or Spanish by trained interviewers. Adult participants were recruited from a variety of community locations including: health and community centers, retail outlets, health fairs, libraries, community college sites, and agricultural meetings of local farmers and ranchers. All data were collected following protocols approved by the University of Texas Health Science Center at Houston (UTHealth) Institutional Review Board (IRB).

The survey consisted of 46 questions; rather than using the technical term "hydraulic fracturing", the informal, universially used term "fracking" was used throughout the survey. The survey covered a range of topics, including demographics (i.e., age, gender, race, ethnicity, education, occupation, and income), chronic health conditions, length of residency in the county, property ownership, proximity of the participants' home to the nearest drilling site, employment by a drilling company, and primary source of drinking water. Knowledge of fracking and potential environmental health effects was assessed via a series of true/false questions and attitudes regarding fracking was assessed by asking partici- 
pants how strongly they agreed or disagreed (using a 5-series Likert scale) to a series of statements.

Additionally, a series of open-ended questions were used to obtain information regarding perceived environmental and health concerns and community impacts of fracking. Specifically, participants were asked: "What do you think are the top three priority environmental issues in your community today?"; "What do you think are the top three priority healthrelated issues in your community today?"; "Are there any environmental factors that you feel are related to the health issues you mentioned?"; and "Thinking about your community before oil and natural gas drilling and production in the Eagle Ford Shale, how have things changed?"

To assess health literacy, the 4-item Brief Health Literacy Screening tool (known as BRIEF) was included in the survey. The BRIEF is a 4-item self-report validated survey measure of health literacy. ${ }^{[22]}$ Participants reported their level of use or confidence in completing each health literacy related task. For three items, participants responded as, "Always, Often, Sometimes, Occasionally, or Never." The fourth item was reported as "Not at all, A little bit, Somewhat, Quite a bit, or Extremely." Three items was coded on a scale of 1 to 5, where 1 refers to low self-reported health literacy and 5 refers to high self-reported health literacy. One item was reverse coded to allow for consistent reporting and scoring. A sum score of the 4-item BRIEF assessment was calculated and participants' health literacy was categorized as inadequate (i.e., sum scores of 4 to 12), marginal (i.e., sum scores of 13 to 16 ), or adequate (i.e., sum scores of 17 to 20). ${ }^{[22]}$

A total of 156 participants completed the survey; three individuals were excluded because they did not report sole residence in one of the three counties. The final sample for this analysis was 153 participants (43 individuals in Atascosa County, 73 individuals in Frio County, and 37 individuals in Karnes County). Given the pilot nature of this study, only descriptive analyses were conducted. Data were summarized and we report medians and interquartile range (IQR), or proportions, as appropriate.

\section{RESUlts}

The overall median age (years) of PaCE survey participants was 50 (interquartile range $[\mathrm{IQR}]=35,59$ ) (see Table 1 ). The median age of participants in Atascosa county was lower than in the other two counties: 40 years $(\mathrm{IQR}=23,48)$ versus 52 years $(\mathrm{IQR}=39,65)$ in Frio county and 55 years (IQR $=44,62$ ) in Karnes county. Overall, $60.8 \%$ of the participants were women and the majority of participants identified as white (75.2\%) and Hispanic (62.1\%). Participants were largely educated; overall, $30.1 \%$ had a high school degree or equivalent and $50.9 \%$ had at least some college. Compared with participants from Atascosa and Frio Counties, more participants in Karnes counties reported an annual household income $\leq \$ 39,999$ (59.5\% versus $44.2 \%$ and $42.4 \%$, respectively). Over half (53.6\%) of the participants classified themselves as landowners and indicated that they had lived in their respective county for more than 21 years $(53.6 \%$ ) (data not shown). When asked to estimate the distance of their residence to the nearest drilling site, $18.3 \%$ of individuals responded " $<2$ miles" while $45.8 \%$ of individuals were unsure of the distance of the nearest drilling site to their home (data not shown). The most prevalent chronic health conditions reported were high blood pressure, arthritis, diabetes, and obesity, and were similar across the counties (data not shown).

Table 1. Selected demographic characteristics of $153 \mathrm{PaCE}$ participants, 2013-2015, by county

\begin{tabular}{|c|c|c|c|c|}
\hline & $\begin{array}{l}\text { Atascosa } \\
n=43\end{array}$ & $\begin{array}{l}\text { Frio } \\
n=73\end{array}$ & $\begin{array}{l}\text { Karnes } \\
\mathbf{n}=\mathbf{3 7}\end{array}$ & $\begin{array}{l}\text { Total } \\
n=153\end{array}$ \\
\hline \multirow[t]{2}{*}{ Age (median [IQR]) } & $40(23,48)$ & $52(39,65)$ & $55(44,62)$ & $50(35,59)$ \\
\hline & n (\%) & n (\%) & n (\%) & n (\%) \\
\hline \multicolumn{5}{|l|}{ Sex } \\
\hline Female & $29(67.4)$ & $35(48.0)$ & $29(78.4)$ & $93(60.8)$ \\
\hline Male & $14(32.6)$ & $38(52.0)$ & $8(21.6)$ & $60(39.2)$ \\
\hline \multicolumn{5}{|l|}{ Race } \\
\hline White & $32(74.4)$ & $56(76.7)$ & $27(73.0)$ & $115(75.2)$ \\
\hline African American & $0(0.0)$ & $1(1.4)$ & $0(0.0)$ & $1(0.7)$ \\
\hline Other & $11(25.6)$ & $15(20.5)$ & $8(21.6)$ & $34(22.2)$ \\
\hline Missing & $0(0.0)$ & $1(1.4)$ & $2(5.4)$ & $3(1.9)$ \\
\hline \multicolumn{5}{|l|}{ Ethnicity } \\
\hline Hispanic & $22(51.2)$ & $49(67.1)$ & $24(64.9)$ & $95(62.1)$ \\
\hline Non-Hispanic & $20(46.5)$ & $23(31.5)$ & $13(35.1)$ & $56(36.6)$ \\
\hline Missing & $1(2.3)$ & $1(1.4)$ & $0(0.0)$ & $2(1.3)$ \\
\hline \multicolumn{5}{|l|}{ Education } \\
\hline$<$ High School & $8(18.6)$ & $12(16.4)$ & $6(16.2)$ & $26(17.0)$ \\
\hline High School/GED & $14(32.6)$ & $18(24.7)$ & $14(37.9)$ & $46(30.1)$ \\
\hline Some College & $11(25.6)$ & $22(30.1)$ & $7(18.9)$ & $40(26.1)$ \\
\hline College Graduate & $8(18.6)$ & $21(28.8)$ & $9(24.3)$ & $38(24.8)$ \\
\hline Refused & $2(4.6)$ & $0(0.0)$ & $1(2.7)$ & $3(2.0)$ \\
\hline \multicolumn{5}{|l|}{ Income } \\
\hline$\leq \$ 39,999$ & $19(44.2)$ & $31(42.5)$ & $22(59.5)$ & $72(47.1)$ \\
\hline$\$ 40,000-\$ 59,999$ & $5(11.6)$ & $14(19.2)$ & $2(5.4)$ & $21(13.7)$ \\
\hline$\geq \$ 60,000$ & $11(25.6)$ & $24(32.9)$ & $6(16.2)$ & $41(26.8)$ \\
\hline Refused & $8(18.6)$ & $4(5.5)$ & $6(16.2)$ & $18(11.8)$ \\
\hline Missing & $0(0.0)$ & $0(0.0)$ & $1(2.7)$ & $1(0.6)$ \\
\hline
\end{tabular}

Note. $\mathrm{IQR}=$ Interquartile range.

Overall, most participants (86.3\%) stated that they had "heard of fracking" (see Table 2). Although the proportion of 
individuals who responded "true" to this statement was lower in Frio County (79.5\%) compared with the other two counties (90.7\% in Atascosa County and $94.6 \%$ in Karnes County) (data not shown). When specifically asked about their fracking-related knowledge, nearly half (46.4\%) of participants denied that they "understood the process of fracking". Most participants reported that they were unaware of potential adult or infant and childhood health effects of fracking (51.7\% and $60.7 \%$, respectively). Fewer individuals (40.0\%) reported being unaware of potential environmental effects of fracking. Participant's attitudes and beliefs regarding fracking are shown in Table 3. Although most of the participants supported fracking in their county $(49.0 \%)$ and indicated that fracking in the EFS created more jobs in their county (79.7\%), they also reported concern about the effects of fracking on the quality of the environment $(65.4 \%)$, as well as the impact of fracking on water quality in their county $(77.8 \%)$.

Table 2. Knowledge regarding fracking among $153 \mathrm{PaCE}$ participants, 2013-2015, by county

\begin{tabular}{lllll}
\hline & $\begin{array}{l}\text { Atascosa } \\
\mathbf{n = 4 3}\end{array}$ & $\begin{array}{l}\text { Frio } \\
\mathbf{n = 7 3}\end{array}$ & $\begin{array}{l}\text { Karnes } \\
\mathbf{n = 3 7}\end{array}$ & $\begin{array}{l}\text { Total } \\
\mathbf{n = 1 5 3}\end{array}$ \\
\hline Statement & \% of participants responding “True” \\
\hline $\begin{array}{l}\text { I have heard of fracking. } \\
\begin{array}{l}\text { I feel that I understand the process of } \\
\text { fracking. }\end{array}\end{array}$ & 90.7 & 79.5 & 94.6 & 86.3 \\
$\begin{array}{l}\text { I am not aware of any potential adult } \\
\text { health effects of fracking.* }\end{array}$ & 55.8 & 56.2 & 46.0 & 53.6 \\
$\begin{array}{l}\text { I am not aware of any potential infant or } \\
\text { childhood health effects of fracking." }\end{array}$ & 52.4 & 64.4 & 62.9 & 60.7 \\
$\begin{array}{l}\text { I am not aware of any potential } \\
\text { environmental effects of fracking. }\end{array}$ & 30.2 & 39.4 & 52.8 & 40.0 \\
\hline
\end{tabular}

*Due to missing responses, $n=42$ for Atascosa, 72 for Frio, and 151 Total; "Due to missing responses, $n=42$ for Atascosa, 35 for Karnes, and 150 Total; ${ }^{5}$ Due to missing responses, $\mathrm{n}=71$ for Frio, 36 for Karnes, and 150 Total.

Table 3. Attitudes and beliefs regarding fracking among 153 PaCE Participants, 2013-2015

\begin{tabular}{|c|c|c|c|}
\hline & $\begin{array}{l}\text { Strongly Agree/ } \\
\text { Agree }\end{array}$ & Neutral & $\begin{array}{l}\text { Disagree/ } \\
\text { Strongly } \\
\text { Disagree }\end{array}$ \\
\hline & n (\%) & n (\%) & n (\%) \\
\hline $\begin{array}{l}\text { Fracking in the Eagle Ford Shale will } \\
\text { create more jobs for residents in my } \\
\text { county.* }\end{array}$ & $122(79.7)$ & 19 (12.4) & $9(5.9)$ \\
\hline $\begin{array}{l}\text { I have approached local officials about } \\
\text { my concerns about fracking in the Eagle } \\
\text { Ford Shale.* }\end{array}$ & $103(67.3)$ & $31(20.3)$ & $16(10.5)$ \\
\hline $\begin{array}{l}\text { I am concerned about the effects of } \\
\text { fracking on the quality of the } \\
\text { environment in my county.* }\end{array}$ & $100(65.4)$ & 38 (24.8) & $12(7.8)$ \\
\hline $\begin{array}{l}\text { I am concerned about the effects of } \\
\text { fracking on the quality of water in my } \\
\text { county.* }\end{array}$ & $119(77.8)$ & $22(14.4)$ & $9(5.9)$ \\
\hline $\begin{array}{l}\text { I think that fracking in my county } \\
\text { should stop until further studies about } \\
\text { how it affects health and the } \\
\text { environment are completed." }\end{array}$ & $53(34.6)$ & $49(32.0)$ & 47 (30.7) \\
\hline I support fracking in my county" & 75 (49.0) & 47 (30.7) & $25(16.3)$ \\
\hline
\end{tabular}

A large proportion of participants (89.5\%) noted changes to their community since oil and gas drilling and production began in their county. Both negative and positive changes were cited, including increased costs of living, increased traffic and road deterioration, and increased employment opportunities (data not shown). More than half $(57.5 \%)$ of the participants stated traffic concerns as a priority environmental issue, primarily due to perceived increases in vehicular accidents. Participants also commonly cited air quality (44.9\%) and water quality/quantity (26.0\%) as priority concerns (see Figure 1). Priority health concerns identified by residents included cancer (34.1\%), diabetes (32.5\%), and respiratory conditions (26.0\%) (data not shown). Approximately one third of all participants (34.6\%) thought that environmental factors were related to the priority health issues identified (data not shown).

Of the 113 participants that completed the health literacy assessment, sum scores indicated marginal or inadequate health literacy for $31.8 \%$ of the participants (see Table 4). Across the three county area we found the most variability with one question, "How confident are you filling out medical forms by yourself?" All other questions were rated high (adequate health literacy), with one item, how often the participant has a problem understanding his/her medical condition, rated highest, indicating adequate health literacy. In this sample, none of the participants reported "often" or "always" having a problem understanding what is told to them about their medical condition (data not shown).

Table 4. Proportion of PaCE participants with adequate, marginal or inadequate health literacy assessed using the BRIEF questionnaire, 2013-2015, by county*

\begin{tabular}{lllll}
\hline & $\begin{array}{l}\text { Atascosa } \\
\mathbf{n = 4 3}\end{array}$ & $\begin{array}{l}\text { Frio } \\
\mathbf{n = 3 3}\end{array}$ & $\begin{array}{l}\text { Karnes } \\
\mathbf{n = 3 7}\end{array}$ & $\begin{array}{l}\text { Overall } \\
\mathbf{n = 1 1 3}\end{array}$ \\
\hline Adequate & 60.5 & 69.7 & 75.7 & 68.1 \\
Marginal & 18.6 & 24.2 & 21.6 & 21.2 \\
Inadequate & 20.9 & 6.1 & 2.7 & 10.6 \\
\hline
\end{tabular}

"BRIEF questions were not included in the survey prior to September 25, 2014; therefore, 37 participants did not have data for this measure; Also, 3 participants did not answer each question and were excluded from the analysis.

\section{Discussion}

The purpose of this exploratory study was to examine community perceptions, knowledge, and concerns regarding environmental health issues pertaining to UOGD in the EFS, given the rapid expansion of drilling in this area. To our knowledge this is the first effort to gather this type of information from residents impacted by drilling activity in these potentially vulnerable and underserved communities. Though most of the participants in this survey had heard 
of "fracking", fewer reported understanding the process and many were unaware of even the potential for environmen- tal or health effects, indicating possible gaps in knowledge. These results highlight the need for education in these communities.

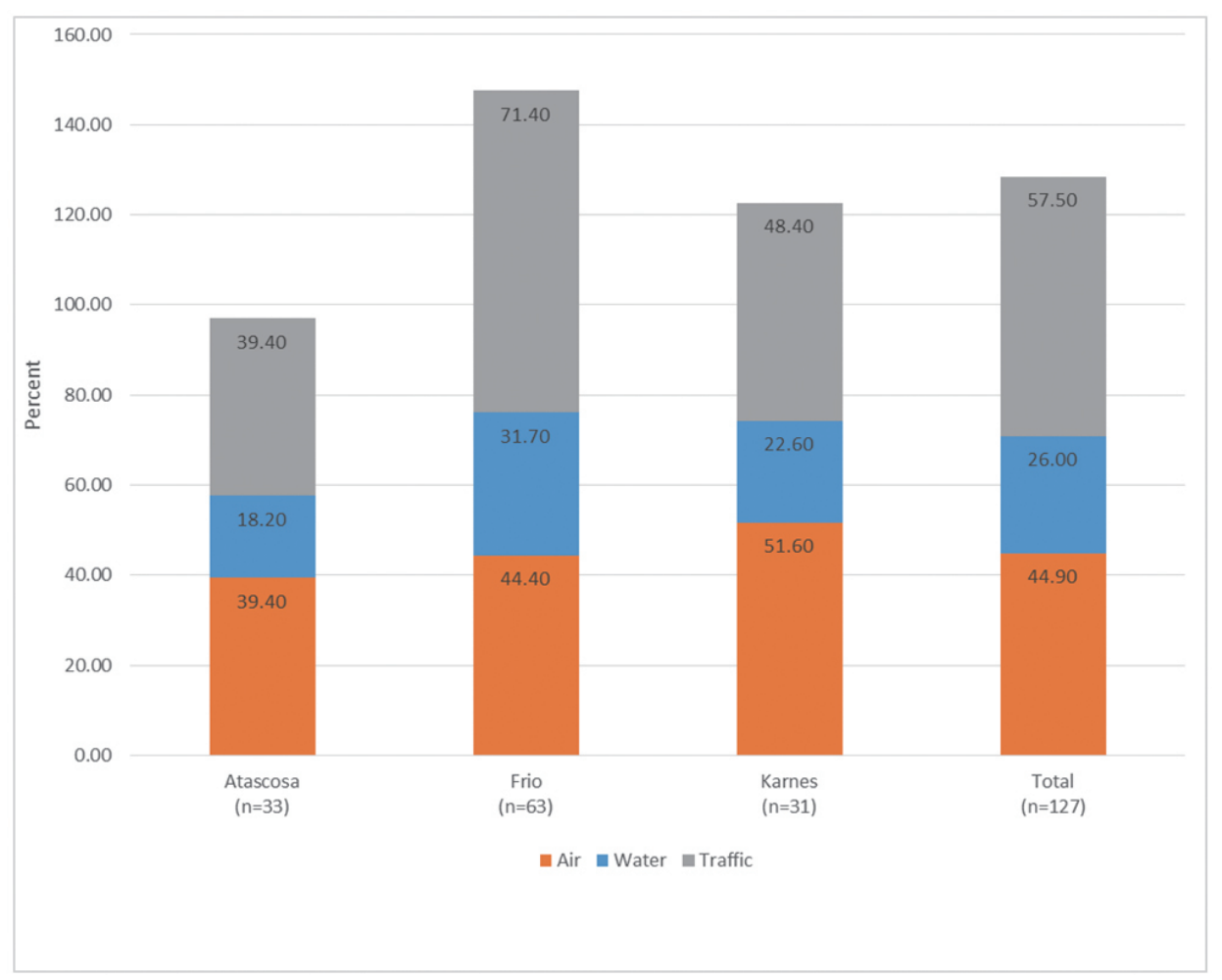

Figure 1. Primary environmental concerns among 127 PaCE participants, by county, 2013-2015. Note, 26 participants did not respond to these questions and are not included in this figure. Additionally, percentages may sum to $>100 \%$ as participants could provide more than one response

Individuals' knowledge and attitudes regarding environmental health may impact their health literacy. ${ }^{[23]}$ Although participants in the present study generally had adequate health literacy as measured by the BRIEF, it is important to note that 1 in 3 participants had marginal or inadequate health literacy which is consistent with other reports of population health literacy. ${ }^{[24,25]}$ Further, in this sample, participants' limited knowledge regarding potential environmental and health impacts of fracking suggests limited environmental health literacy (EHL). Given findings indicating general health literacy as a greater predictor of health outcomes than race/ethnicity or income, it is important that methods to assess environmental literacy be further developed. ${ }^{[26]} \mathrm{EHL}$ is an emerging and evolving concept that bridges shared theories from the fields of health literacy, risk communication, environmental health science, behavioral science, public health, and other social sciences to represent skills related to identification and use of environmental information. ${ }^{[27-30]}$ A challenge to understanding and addressing the influence of poor EHL is the potential mismatch between the public's perceptions of exposure and related risks and the often complex terminology and numeracy associated with environmental health risk information. Messaging and dissemination of important environmental health information, including such information related to fracking, comes from various sources, family, friends, the media and written channels, and often includes specific numerical and technical information that may be difficult for many to interpret and translate in terms of risk. ${ }^{[27,31,32]}$ The National Institute of Environment Health Sciences (NIEHS) has been instrumental in advocating for the advancement in the field of EHL. ${ }^{[27,33,34]}$ Among its strategic goals are "to increase scientific literacy and generate awareness of the health consequences of environmental exposures" and "to understand the disproportionate risks of disease and to define and support public health and prevention solutions in affected populations."[35]

Given identified gaps in understanding potential frackingrelated environmental health issues identified in the present study, we expect that the fracking knowledge-related questions used in our study may serve as a potential indicator 
of inadequate EHL. Given the lack of a specific EHL assessment tools we are unable to explicitly assess the level of EHL in these communities. As pointed out by Finn and O'Fallon, ${ }^{[27]}$ there is currently little understanding of the social and cultural contexts which inform the ways in which the general public understand environmental health risks. These social and cultural contexts may be particularly important to understanding environmental health-related attitudes and perceptions in vulnerable communities, such as those living near UOGD in the EFS.

Several limitations to this study must be noted. Because this was an exploratory pilot study, individuals were selected as part of a convenience sample; thus, there may be selection bias present. Compared with county-level estimates from the U.S. Census (https://factfinder. census.gov), there were some differences in the demographic composition of participants from the three counties. In each county, the median age of participants was older than the median age for the entire county, although this study was restricted to adults. Compared with U.S. Census estimates, in Frio County, a greater proportion of individuals were Hispanic; in Karnes County, a greater proportion of individuals were female and Hispanic; in Atascosa County, a greater proportion of individuals were female. Nonetheless, given the pilot nature of this study, the goal was to begin to assess attitudes and perceptions of environmental health issues in this county and the results were not intended to be generalized to all residents of the area. Second, while an assessment of EHL is lacking, the use of a validated self-reported health literacy assessment which revealed marginal or inadequate health literacy among many of the participants points to the need to develop and validate a specific EHL assessment. The inclusion of environmental questions related to knowledge and attitudes overall poor levels of understanding of fracking and lack of knowledge regarding potential environmental health impacts. We also posit that the self-reported health literacy scores may be inflated due to stigma associated with report of problems reading and completing forms, and therefore, health literacy scores may be lower if assessed within a specific skill based context focused on identification, processing and use of environmental health exposure or risk information.

Few studies regarding water or air quality in counties near the EFS have been conducted and, to our knowledge, no epidemiologic studies examining the health impacts of po- tential exposure have been conducted among individuals living near UOGD in the EFS. However, research in other regions of the United States provide evidence of potential exposure and associated adverse health outcomes, including increased hospitalizations and risk of some adverse birth outcomes. ${ }^{[15,16,18,19]}$ Public health and community engagement activities regarding hydraulic fracturing also appear to be limited. Several concerns identified through a health impact assessment in a community in western Colorado, ${ }^{[20]}$ including concerns about crime and substance abuse, were shared by the participants in the present study, although these concerns did not rank amongst the top three. Further, a recently published study indicating evidence of environmental justice regarding the location of wastewater disposal wells in the EFS, with wells disproportionately located near homes of people of color. ${ }^{[36]}$ There is scarce data regarding specific chemical and physical exposures experienced by communities living near UOGD activities in the EFS yet the potential for particular groups within these communities to be disproportionately affected and overburdened by such exposures is great. This, coupled with an apparent lack of knowledge by the community regarding potential exposures and impacts indicates a need for increased activities related to exposure assessment, education, awareness, and outreach in these South Texas communities.

In this sample, we found limited knowledge of fracking and related impacts in a community with increased UOGD activities and therefore, potential environmental health risk. Of concern is the limited of understanding of fracking may lead to myths and misconceptions related to environmental health risks and possibly increase concerns regarding risk of exposure within communities. This exploratory study justifies further research to assess EHL in this and similar communities as well as targeted educational campaigns.

\section{ACKNOWLEDGEMENTS}

This project was supported by the National Center for Advancing Translational Sciences, National Institutes of Health, through Grant UL1 TR001120. The content is solely the responsibility of the authors and does not necessarily represent the official views of the NIH.

\section{CONFlicts OF InTEREST Disclosure}

Authors declare that they have no competing interests. 


\section{REFERENCES}

[1] U. S. Energy Information Administration. 2015 Annual Energy Outlook. http://www.eia.gov/forecasts/archive/aeo15/. Accessed May 25, 2016.

[2] Adgate JL, Goldstein BD, McKenzie LM. Potential Public Health Hazards, Exposures and Health Effects from Unconventional Natural Gas Development. Environmental Science \& Technology. 2014; 48(15): 8307-8320. PMid:24564405 https://doi.org/10.102 $1 /$ es404621d

[3] Coons T WR. Community health risk analysis of oil and gas industry in garfield county Grand Junction, CO. 2008. Available from: http://www.garfield-county.com/public-health/docu ments/1._COMMUNITY_HEALTH_RISK_ANALYSIS- (Complete _Report_16MB) .pdf. Accessed February 21, 2014.

[4] Shonkoff SB, Hays J, Finkel ML. Environmental Public Health Dimensions of Shale and Tight Gas Development. Environmental Health Perspectives. 2014; 122(8): 787-189. https://doi.org/ $10.1289 /$ ehp. 1307866

[5] McKenzie LM, Witter RZ, Newman LS, et al. Human Health Risk Assessment of Air Emissions from Development of Unconventional Natural Gas Resources. Science of The Total Environment. 2012; 424: 79-87. PMid:22444058 https://doi.org/10.1016/j.sc itotenv . 2012.02.018

[6] Colborn T, Schultz K, Herrick L, et al. An Exploratory Study of Air Quality near Natural Gas Operations. Human and Ecological Risk Assessment. 2014; 20: 86-105. https://doi.org/10.1080/10 807039.2012 .749447

[7] Helmig D, Thompson CR, Evans J, et al. Highly Elevated Atmospheric Levels of Volatile Organic Compounds in the Uintah Basin, Utah. Environmental Science \& Technology Environ. Sci. Technol. 2014; 48(9): 4707-4715. PMid:24624890 https ://doi .org/10.1 021/es405046r

[8] Macey GP, Breech R, Chernaik M, et al. Air Concentrations of Volatile Compounds Near Oil and Gas Production: A CommunityBased Exploratory Study. Environmental Health Perspectives. 2014; 13(82). https://doi .org/10.1186/1476-069x-13-82

[9] Zielinska B, Campbell D, Samburova V. Impact of emissions from natural gas production facilities on ambient air quality in the Barnett Shale area: A pilot study. Journal of the Air \& Waste Management Association. 2014; 64(12): 1369-1383. https://doi.org/10.1 $080 / 10962247.2014 .954735$

[10] Kassotis CD, Iwanowicz LR, Akob DM, et al. Endocrine disrupting activities of surface water associated with a West Virginia oil and gas industry wastewater disposal site. Science of The Total Environment. 2016; 557-558: 901-910. PMid:27073166 https: //doi.org/10.1016/j.scitotenv.2016.03.113

[11] Hildenbrand ZL, Carlton DD, Jr., Fontenot BE, et al. A Comprehensive Analysis of Groundwater Quality in The Barnett Shale Region. Environmental Science \& Technology. 2015; 49(13): 8254-8262. PMid:26079990 https://doi.org/10.1021/acs.est.5b0152 6

[12] United States Environmental Protection Agency. Assessment of the Potential Impacts of Hydraulic Fracturing for Oil and Gas on Drinking Water Resources (External Review Draft). 2015.

[13] Werner AK, Vink S, Watt K, et al. Environmental health impacts of unconventional natural gas development: a review of the current strength of evidence. Science of the Total Environment. 2015; 505: 1127-1141. PMid:25461113 https://doi.org/10.1016/j. scitotenv.2014.10.084

[14] Fryzek J, Pastula S, Jiang X, et al. Childhood Cancer Incidence in Pennsylvania Counties in Relation to Living in Counties With
Hydraulic Fracturing Sites. Journal of Occupational and Environmental Medicine. 2013; 55(7): 796-801. PMid:23836020 https : //doi.org/10.1097/JOM.0b013e318289ee02

[15] McKenzie LM, Guo R, Witter RZ, et al. Birth Outcomes and Maternal Residential Proximity to Natural Gas Development in Rural Colorado. Environmental Health Perspectives. 2014; 122(4): 412417. https://doi.org/10.1289/ehp. 1306722

[16] Casey JA, Savitz DA, Rasmussen SG, et al. Unconventional Natural Gas Development and Birth Outcomes in Pennsylvania, USA. Epidemiology. 2015; 27(2): 163-172. https://doi.org/10.1097/ ede. 0000000000000387

[17] Tustin AW, Hirsch AG, Rasmussen SG, et al. Associations between Unconventional Natural Gas Development and Nasal and Sinus, Migraine Headache, and Fatigue Symptoms in Pennsylvania. Environmental Health Perspectives. 2016: Epub ahead of print. PMid:27561132 https : //doi .org/10.1289/EHP281

[18] Stacy SL, Brink LL, Larkin JC, et al. Perinatal Outcomes and Unconventional Natural Gas Operations in Southwest Pennsylvania. PLoS ONE. 2015; 10(6): e0126425. PMid:26039051 https : //doi.org/10.1371/journal.pone.0126425

[19] Jemielita T, Gerton GL, Neidell M, et al. Unconventional Gas and Oil Drilling Is Associated with Increased Hospital Utilization Rates. PLoS ONE. 2015; 10(8). https://doi .org/10.1371/journal. pone. 0137371

[20] Witter RZ, Mckenzie LM, Stinson KE, et al. The Use of Health Impact Assessment for a Community Undergoing Natural Gas Development. American Journal of Public Health. 2013; 103(6): 1002-1010. PMid:23597363 https://doi.org/10.2105/AJPH. 2012.3010 17

[21] The Railroad Commission of Texas. Eagle Ford Shale Information Available from: http://www.rrc.state.tx.us/oil-gas/maj or-oil-gas-formations/eagle-ford-shale/. Accessed October 12,2015

[22] Haun J, Noland-Dodd V, Varnes J, et al. Testing the BRIEF Health Literacy Screening Tool. Federal Practitioner. 2009; 26(12): 24-31.

[23] Ratnapradipa D, Middleton WK, Wodika AB, et al. What does the public know about environmental health? A qualitative approach to refining an environmental health awareness instrument. Journal of Environmental Health. 2015; 77(8): 22-28. PMid:25876262

[24] Kirsch I, Jungeblut A, Jenkins L, et al. Adult Literacy in America: A First Look at the Results of the National Adult Literacy Survey. Washington D.C.: National Center for Education Statistics, U.S Department of Education. 1993.

[25] U.S. Department of Education Institute of Education Sciences National Center for Education Statistics. 2003 National Assessment of Adult Literacy. https://nces.ed.gov/naal/health_results . asp. Accessed June 15, 2016.

[26] Nielsen-Bohlman L, Panzer AM, Kindig DA. Health literacy: a prescription to end confusion. Institute of Medicine. 2004.

[27] Finn S, O'Fallon L. The Emergence of Environmental Health Literacy-From Its Roots to Its Future Potential. Environmental Health Perspectives. 2015: Epub ahead of print. PMid:26126293 https://doi.org/10.1289/ehp.1409337

[28] Biocca M. Risk Communication and the Precautionary Principle. Human and Ecological Risk Assessment: An International Journal. 2005; 11(1): 261-266. https ://doi.org/10.1080/1080703059 0920097

[29] Chinn D. Critical health literacy: A review and critical analysis Social Science \& Medicine. 2011; 73(1): 60-67. PMid:21640456 https://doi.org/10.1016/j.socscimed.2011.04.004

[30] Fitzpatrick-Lewis D, Yost J, Ciliska D, et al. Communication about environmental health risks: a systematic review. Environ Health. 
2010; 9: 67. PMid:21040529 https://doi.org/10.1186/1476 $-069 \mathrm{X}-9-67$

[31] Kennedy MG, Turk EE, Wilson-Genderson M, et al. Effects of a television drama about environmental exposure to toxic substances. Public Health Reports. 2011; 126(1): 150. PMid:21563723 https://doi.org/10.1177/00333549111260S119

[32] Moore EE. Green Screen or Smokescreen? Hollywood's Messages about Nature and the Environment. Environmental Communication. 2016; 10(5): 539-555. https://doi.org/10.1080/17524032.2 015.1014391

[33] O'Fallon LR, Dearry A. Commitment of the national institute of environmental health sciences to community-based participatory research for rural health. Environmental Health Perspectives. 2001; 1009(3): 469-473. https://doi.org/10.2307/3434797

[34] Brown P, Brody JG, Morello-Frosch R, et al. Measuring the success of community science: The northern California household exposure study. Environmental Health Perspectives. 2012; 120(3): 326-331. PMid:22147336 https : //doi .org/10.1289/ehp.1103734

[35] National Institute of Environmental Health Sciences. 2012-2017 strategic plan. Available from: http://www.niehs.nih.gov/ab out/strategicplan/index.cfm

[36] Johnston JE, Werder E, Sebastian D. Wastewater Disposal Wells, Fracking, and Environmental Injustice in Southern Texas. American Journal of Public Health. 2016; 106(3): 550-556. PMid:26794166 https://doi.org/10.2105/AJPH. 2015.303000 